\title{
Nationalism and development: an alternative for Mexico
}

\author{
Gaspar Núñez Rodríguez and \\ José Antonio Romero Tellaeche
}

\begin{abstract}
The most developed countries have generally had an active State, a driving, regulatory and protectionist State, among other roles, although the most consolidated concept seems to be that of a developmental State. In this paper, a social accounting matrix of Mexico is constructed in order to design a dynamic-recursive applied general equilibrium model to analyse and quantify the impact of policies that were promoted by the State; in particular, policies aimed at increasing private savings and subsidies for the consumption of domestic inputs. The implementation of these simple policies was found to have a substantial positive impact overall, from which important economic policy elements for a development strategy emerge.
\end{abstract}

\section{Keywords}

Nationalism, economic development, social development, economic policy, development strategies, econometric models, social accounting, Mexico

JEL classification

C68, D58, E16, O21, O41, O54

\section{Authors}

Gaspar Núñez Rodríguez is a researcher with the Economic Analysis Programme of Mexico (PRAEM) of the Center for Economic Studies (CEE) at El Colegio de México. Email: gaspar.nunez@colmex.mx.

José Antonio Romero Tellaeche is a Research Professor with the Center for Economic Studies (CEE) at El Colegio de México. Email: jromero@colmex.mx. 


\section{Introduction}

The economic stagnation and growing inequality that Mexico has experienced over the last three decades have led many scholars to propose simplistic solutions to help the country catch up, as illustrated by the idea that has been reiterated of forging a fair and inclusive Mexico (CCO Noticias, 2015). However, countries that have achieved rapid growth have motivated their populations to work harder and make greater sacrifices on the basis of a fierce nationalism.

Hirschman (1958) identifies nationalism as the "binding agent" of East Asian development in the context of "late development"; it is not an unjustified nationalism, but one that emerged as a reaction to war and imperialism, and which manifested itself in different ways: communism in China and the Democratic People's Republic of Korea and the capitalist developmental State in Japan, the Republic of Korea and Taiwan Province of China. This is also why the East Asian developmental States have more in common with the late-developing European nations of the nineteenth century, such as Germany, and less in common with contemporary developing societies in Latin America and other regions (Greenfeld, 1993; Hirschman, 1958 and 1968; Johnson, 1982; Woo-Cumings, 1999).

Nationalism helps to provide the initial impetus for development and is, in turn, strengthened by that development. To grow, Mexico must once again resort to nationalism and boost its self-esteem; it must aspire to be more than just a fairer and more inclusive country (CCO Noticias, 2015). Most countries that have achieved economic well-being have not set it as a goal, but have achieved it as a by-product of development. Mexico has the size and the elements to become a middle power; with a population of just over 100 million, it can aspire to play a leading role in the international community, on the same level as countries such as Japan, the Russian Federation or Germany, all of which have populations similar in size to Mexico's. To achieve this, planning for development should be undertaken, as successful countries have done.

It is not necessary to invent something new for this. One need only look at countries that managed to develop in a few decades, as Germany did in the nineteenth century (Lee, 1991; Pierenkemper and Tilly, 2004), Japan in the early twentieth century, the Republic of Korea and Taiwan Province of China in the second half of the twentieth century, China in the late twentieth and early twenty-first centuries and, more recently, Viet Nam. Studying these countries reveals that they all had a genuine intention to develop and that they planned their economies to accelerate development and catch up with the leading countries within a few decades. All of them adopted a developmental State model, defined as seeking accelerated capitalist development through planning by means of a consensual rational plan, which combines private property with State control, in other words, managed capitalism (Amsden, 1992; Chibber, 2014; Evans, 1995; Kasahara, 2013; Kim, 1999; Kristof and WuDunn, 2000; Leftwich, 1994 and 1995; Maman and Rosenhek, 2011; Minns, 2001; Nabi and Shivakumar, 2001; Öniş, 1991; Polidano, 2001; Thompson, 1996; Vogel, 1991; Wade, 2003; Wan, 2008; Weiss, 2000; Wong, 2004; Woo-Cumings, 1999).

The stylized components of this strategy include: (i) a strong State; (ii) a nationalism capable of leading the population to make sacrifices now for the country's future development; (iii) an efficient bureaucracy and, within it, an elite body with broad economic and social planning powers; ${ }^{1}$ (iv) policies to encourage saving

\footnotetext{
In Japan, after the Second World War, a strong link was re-established between the government and big business. The civil service and the private sector worked together to establish this link, through which the government implemented an administrative management system with key government departments, such as the Ministry of International Trade and Industry and the Ministry of Finance, which actively participated in protecting and subsidizing companies whose activities were in line with national priorities. The equivalent of Japan's Ministry of International Trade and Industry in the Republic of Korea was the Ministry of Trade and Industry, which helped to create and implement the government's industrial policies in the latter country (Chen, 1995).
} 
(or discourage consumption); ${ }^{2}$ (v) not allowing foreign investment or only allowing highly regulated foreign investment, as in the case of China (Alfaro and Charlton, 2013; Chang, 2003; Rodriguez and Rodrik, 1999; Paul, 1979); (vi) a strong, State-controlled financial system to channel national savings and foreign loans to strategic sectors (Skocpol, 1985; Chandrasekhar, 2013; Rashid, 2013; Woo-Cumings, 1999; Johnson, 1987; Zysman, 1983); ${ }^{3}$ (vii) selecting strategic sectors according to their capital intensity, increasing returns, ${ }^{4}$ learning and innovation economies, among other characteristics, ${ }^{5}$ and high income elasticity of demand; ${ }^{6}$ (viii) key sectors with tariff protection, access to foreign exchange and financial support based on their performance (Aoki, Kim and Okuno-Fujiwara, 1998); (ix) educational and scientific and technological policies based on these objectives; ${ }^{7}$ and $(x)$ using the exchange rate to make the economy more competitive (Rodrik, 2007).

None of the aforementioned components can be considered in isolation, rather they are part of the overall strategy; no policy makes sense on its own, its importance lies in the fact that it contributes to achieving the ultimate goal, which is the greatness of the nation.

To analyse the potential effects of adopting a developmental State model in Mexico, we designed a recursive dynamic computable general equilibrium (CGE) model, which is based on a social accounting matrix, constructed from the 2012 input-output matrix, published by the National Institute of Statistics and Geography (INEGI, 2016), and additional information from the national accounts. The model considers consumers, the government, factors, productive sectors and the external sector. Consumers and the government consume domestic and imported goods and also save. Businesses use labour, capital and intermediate goods to produce the final good. Intermediate goods are domestic and imported. The price system and the level of income motivate the decisions of all economic agents. The model's prime characteristic is the inclusion of increasing returns, which is the core that gives meaning to the developmental State model strategy.

The model assumes a strong and legitimate government, robust nationalism, an efficient civil service and government control of the financial system, allowing it to channel resources to strategic sectors by mandate. The CGE model allows us to analyse the effects of different trade policies (tariffs on or subsidies for certain types of imports, taxes on or subsidies for certain exports), changes in the exchange rate, or the use of taxes or subsidies to limit or expand overall consumption (to reduce or increase private savings) or certain types of products. Similarly, the CGE model can simulate restrictions on the entry of aggregate foreign investment and could be modified to analyse the effects of selective regulation of foreign investment by industry.

The CGE model is used to simplify and at the same time illustrate the possibilities of the developmental model, as it allows the effects of only two policies to be analysed. Specifically, it is

2 Much of the Asian countries' success is attributed to the traditional Confucian ethics, which prizes qualities such as diligence, frugality, family solidarity and group harmony, and puts an emphasis on education. For other developing countries, these examples serve as a reminder that if they want to apply the lessons of East Asia's experiences, it is not enough to merely imitate the economic and institutional aspects of those experiences, they must also factor in the cultural aspects that played a key role in East Asia's achievements. This is not to say that other developing countries need to adopt Confucian tradition. Rather, it is to remind them of the beneficial effects that certain, country-specific cultural traits bring and to take advantage of them and cultivate them to achieve the desired purposes (Liang, 2010). Similarly, the launch of a pension plan in Singapore, based on individual contributions, led to significant increases in savings (Monetary Authority of Singapore, 1991).

3 In this regard, Skocpol (1985) states that "All these sorts of questions must be asked in any study of state capacities. [...] A state's means of raising and deploying financial resources tell us more than could any other single factor about its existing (and immediately potential) capacities to create or strengthen state organizations, to employ personnel, to coopt political support, to subsidize economic enterprises and to fund social programmes" (p. 17).

4 See Young (1928) for an excellent explanation of the importance of increasing returns.

5 See Kim and Nelson (2000), Nelson (1996), Rasgotra (2013), Taylor (2016) and Shin and Chang (2003) for explanations of the importance of sectors' technological innovation capacities.

6 See analysis of sector selection in Felipe (2015) and Falck, Gollier and Woessmann (2011).

7 The complementarity between education and other factors is commonly seen as the driving force behind economic growth and efficiency in East Asia. East Asian education systems are formed and extended in close relation to the stages of economic development: the higher the level of economic development, the greater the demand for better and higher education systems (Permani, 2009). 
assumed that: (i) subsidies for the use of national inputs are provided to key sectors, but not the remaining sectors; and (ii) the population can be motivated to save more, not through consumption taxes -as in the Republic of Korea (Liang, 2010) or Singapore (Huff, 1995) - and that the government can channel these increased savings towards key sectors (those with above-average indices of power of dispersion (backward linkages) and sensitivity of dispersion (forward linkages)). ${ }^{8}$

Protectionist measures and efforts to promote exports are not mutually exclusive. The Asian growth model has been presented as one in which growth is achieved through exports, as opposed to the unsuccessful Latin American model of import substitution. This misguided dichotomy contrasted a protectionist and inefficient Latin America with Asian economies that opened their borders to international competition and benefited from growing international demand through trade based on their comparative advantages. Analysis of the success stories of Japan in the nineteenth and twentieth centuries, the Republic of Korea and Taiwan Province of China in the twentieth century, and, more recently, China and Viet Nam, and the role played by foreign trade or foreign direct investment (FDI), shows that this is not a linear relationship.

The respective governments of these countries offered interesting incentives at the time, such as preferential loans, licences that limited domestic and external competition, and tariffs or access to foreign currencies at advantageous official prices, but at the same time they set export targets in order to reduce current account deficits. The mandatory export targets would, over time, have a greater benefit than balancing the external sector. The targets forced the business owners of these countries to perform well in a market that was not managed and, consequently, in which they did not have privileges, unlike their domestic markets. Making profits in a market where licences eliminated the possibility of competition did not produce an inefficient productive fabric; on the contrary, German (karteles), Japanese (zaibatsu), Korean (chaebol) or Chinese conglomerates could artificially lower export prices, below their own costs, in order to achieve the given export target and offset these losses with the bumper profits made in their domestic market. Foreign markets thus allowed and still allow the local dangers of industrial policy incentives to be corrected (Berasaluce and Romero, 2018).

For our proposed CGE model, it is assumed that in some sectors there are increasing returns to scale. These increasing returns are internal to an industry, but external to a firm, allowing the perfect competition assumption to be maintained (Helpman and Krugman, 1985). Because we work with increasing returns, the model does not reach a stable state. Ten time periods are used and the CGE model has 47 sectors.

This paper is organized as follows: in section II, the function used of increasing returns to scale is explained in detail and substantiated; in section III, the database, the construction of the social accounting matrix and the selection of key sectors are described; in section IV, the proposed CGE model is described (see the mathematical model in annex $\mathrm{A} 3$ ); in section $\mathrm{V}$, the proposed simulation is carried out and the results are analysed; and lastly, in section $\mathrm{VI}$, the paper concludes with some final comments and reflections.

\section{Increasing returns ${ }^{9}$}

Although increasing returns to scale may have several causes, the division of labour has traditionally been cited as the main one. According to Sánchez (2011), Adam Smith's ideas on this subject were later improved upon by Young (1928) and then indirectly by a number of development economists -Rosenstein-Rodan (1943), Nurkse (1952), Hirschman (1958), Myrdal (1971) and Prebisch (1959), among others - for whom industry was the engine of growth, either because of increasing returns to scale or because of its productive linkages.

\footnotetext{
8 The CGE model can perfectly simulate this objective through consumption taxes, but we consider that the assumption that the increase in savings is a voluntary measure, taken for non-economic reasons, induced a national sentiment, which goes beyond individualism and with a view to achieving a strong and powerful nation, is more consistent with the developmental model.

9 This section is based on Young (1928).
} 
More recently, other authors have made important conceptual additions, most notably the works of Krugman (The Nobel Prize, 2020) and Helpman and Krugman (1985), on which the concept of increasing returns to scale used in this research is based.

A huge body of empirical work has been developed at the international level to test the hypothesis of increasing returns to scale in real economies and to estimate parameters that account for the amounts. For example, Antweiler and Trefler (2000) found that "the Helpman-Krugman framework provides a remarkable lens for viewing the scale elasticities encoded in trade flows. In particular, we find that a third of all goods-producing industries are characterized by scale. (The modal range of scale elasticities for this group is 1.10-1.20 and the economy-wide scale elasticity is 1.05)".

In the specific case of Mexico, studies have also been carried out that show that the potential effects on the country are significant. Castañeda and Garduño (2000) estimate a returns to scale index for Mexican manufacturing industries, in a paper that finds considerable evidence of increasing returns to scale, and they conclude that, considering the results of the pooled data, six sectors comprising 21 industries present evidence of increasing returns to scale. In two-digit estimates, 19 industries show increasing returns to scale.

Sánchez (2011) analyses the stagnation in Mexico's relationship with manufacturing and increasing returns using a Kaldorian approach. Using a series of econometric models, he tests Kaldor's three growth laws and finds, among other results, that the estimate of the law using Kaldor's specification indicates that the degree of increasing returns is around 2.98 in the Mexican regions, the Wald test indicates that this value is statistically significant.

Meanwhile, increasing returns to scale have also been used in applied theoretical works to demonstrate empirical implications in applied general equilibrium models, as López-de-Silanes, Markusen and Rutherford (1992) do in the case of Mexico.

In accordance with the papers previously referred to for this research, based on the proposal of Helpman and Krugman (1985) for a production function with increasing returns to scale $Y=g(Y) \tilde{f}(v)$, where $v$ is the input vector, we propose a function of increasing returns to scale with the specific

functional form $g=\left(\frac{Y_{t}}{Y_{t-1}}\right)^{\mu}$, where $Y_{t}$ is the current production level and $Y_{t-1}$ the previous one; $\mu$ can be specified at different levels to achieve more or less high degrees of increasing returns to scale; in

the main simulation, we specified $\mu=1.5$ for 12 key sectors, which is consistent with the results of Sánchez (2011) and Castañeda and Garduño (2000) for Mexico. For the remaining 35 sectors, we specified $\mu=0$ (in other words, they do not develop increasing returns to scale). It should be noted that this is a very conservative assumption, as economic growth would also generate increasing returns, to some degree, in non-key sectors; in simulations with a greater for either of the two groups (or for both), as expected, the results obtained are always higher as $\mu$ increases.

\section{Data and social accounting matrix}

A social accounting matrix is built on the concept of the circular flow of the economy, able to capture all these flows with greater or lesser disaggregation; in turn, the social accounting matrix is the standard database that underpins the CGE model.

Households own the factors of production, which businesses pay them for and then use to produce goods and services that they sell to households. It is assumed that, in each productive cycle, the economy reaches an equilibrium that allows agents to optimize their behaviour, and that the factor and goods markets are cleared. 
The government collects taxes from households and businesses to provide services and, lastly, the country's economy exchanges goods with the rest of the world.

The circular flow of the economy generates, in turn, a circular flow of income with a counter-flow of goods and factors. When firms pay for capital and labour, they generate an income for households, which they use to buy the goods produced; firms in turn use that income to rehire capital and labour, and so on.

To prepare the social accounting matrix that is the database that underpins the design, calibration and implementation of the model, the national symmetric input-output tables, published by INEGI for 2012 (INEGI, 2016) (aggregated to 47 productive activities), were used as a starting point, together with national accounts data to close the accounts. We also used the imports origin-destination matrix (INEGI, 2016), a novel feature of our model, which allows the constant elasticity of substitution (CES) combination of domestic and foreign inputs used in each case (compound inputs) to be broken down in detail.

To determine which sectors benefit from an active domestic input subsidy policy (with the effect of increasing domestic content), we used key sector analysis based on Rasmussen's (1956) indices ${ }^{10}$ (see annex A1). Twelve sectors were selected, namely: electric power generation; food manufacturing; paper manufacturing; petroleum and coal products manufacturing; chemical manufacturing; plastics and rubber products manufacturing; primary metal manufacturing; fabricated metal product manufacturing; machinery manufacturing; computer, communications and other equipment manufacturing; electrical equipment, appliance and component manufacturing; and transportation equipment manufacturing. ${ }^{11}$

\section{Recursive dynamic computable general equilibrium (CGE) model}

This section provides an intuitive description of the model. Annex A2 contains the list of parameters and variables as a reference for the subsequent specification of the mathematical model. Table A2.1 in annex A2 describes the parameters to be calibrated with the economy's data from the social accounting matrix. Similarly, table A2.2 describes the variables in the model. The mathematical model is specified in annex A3.

\section{Households}

In the social accounting matrix, Mx12, households are aggregated into an account that concentrates all private income in the first row of the matrix and all expenditure in the first column. In the economy represented by the social accounting matrix, households earn income from capital income, wages and salaries, government transfers and transfers from the rest of the world (RoW) (remittances).

Meanwhile, households pay taxes and the rest of their disposable income is used for savings (future consumption) and consumption of goods and services (present consumption). In turn, consumption of goods and services is broken down into two groups, a national aggregate good and an imported aggregate good.

\footnotetext{
${ }^{10}$ Rasmussen's (1956) indices consist of calculating the average magnitudes of the power of dispersion (backward linkages) and sensitivity of dispersion (forward linkages) for each of the productive sectors and comparing them with the global average, in order to identify the "key sectors", which are those whose forward and backward linkages are above the average. In this paper we use them to define the sectors that benefit from a specific public policy and, at the same time, to identify the sectors with increasing returns to scale.

11 See Castañeda and Garduño (2000) for a study finding positive economies of scale in Mexico.
} 


\section{Government}

The government collects taxes: on income, on products and on production. It uses these to makes transfers to households (programmes to combat poverty and other issues), saves a proportion and devotes the rest to the purchase of domestic and imported goods.

\section{Savings and investment}

The savings and investment account gathers together the savings of economic agents: households, firms, government and the rest of the world (balance-of-payments current account, which is equivalent to net lending from the rest of the world), to finance the purchase of capital goods (gross fixed capital formation, including changes in stocks). Some capital goods come from the total domestic supply and some from the rest of the world.

\section{Productive factors}

The economy has an initial undifferentiated capital endowment and a labour endowment, that is also uniform. This implies full factor mobility among productive activities, which in turn suggests a long-term time horizon, that is to say that, eventually capital can be transformed and transferred from one activity to another depending on the stimuli generated by changes in relative prices. The same applies to labour.

\section{Production}

The production of the total supply of goods and services in the economy is modeled through the following nesting: first the value added is produced through a Cobb-Douglas function; at the same level, a composite input (domestic and imported inputs) is generated through a CES function; at the next level, the total supply production is estimated with a Leontief function.

Given its complexity, nesting production is standard practice for the design and implementation of computable general equilibrium models, otherwise it would be unmanageable in terms of both the mathematical specification of the models and their computational implementation (see, for example, Lofgren, Harris and Robinson, 2002).

\section{Rest of the world (RoW)}

The rest of the world receives income from imported inputs and capital goods, as well as from direct imports by the public and private sectors, and also takes a share of capital income, mainly as payment for property rents. The expenses incurred by the rest of the world are transfers to households (remittances); payment for labour (documented); exports; and savings (net lending from the rest of the world).

\section{Macroeconomic closures}

The macroeconomic closures specified in the simulations are:

(i) fixed marginal propensity to save and variable investment;

(ii) fixed tax rates and variable receipts; and

(iii) fixed exchange rate and variable income from the rest of the world. 


\section{Recursive dynamics}

Dixon and Parmenter (1996) consider four dynamic modelling cases. In this model, we followed the first case, in which investment is exogenous, consistent with expectations of limited scope, savings rates are given and savings are equal to investment in each period. The population (labour) is growing at a constant rate $g_{0}$. For the recursive dynamics, we used external growth projections for the economically active population (EAP), on average 1.6\% per period (Partida, 2008).

\section{Simulations and results}

We simulate a growth-enhancing policy based on two elements: an increase in households' marginal propensity to save as a result of moralistic exhortations (such as the message disseminated in the Republic of Korea: "spend what is left after saving" (Park, 1979) or through direct consumption taxes and subsidies on the use of domestic inputs. As mentioned above, it is assumed that 12 key sectors show increasing returns to scale in both the baseline scenario and the simulations.

\section{Baseline scenario}

To obtain the baseline scenario over a time horizon divided into 10 periods, we started from the capital accumulation rate observed in year zero (initial balance) and, as indicated above, from labour factor growth of $1.6 \%$ on average, in accordance with the projections of Partida (2008).

The input-output matrices published by INEGI (2016), which is the source used, include all wages paid in the economy, including those in the informal sector. For the purposes of this analysis, it is not necessary to disaggregate wages by formal and informal sector; it should be noted, however, that in the manufacturing sector virtually all work is formal (see table 1).

Table 1

Composition of total value added and of the labour factor

(Millions of constant 2012 pesos)

\begin{tabular}{lr}
\hline Gross value added (basic prices) & 15106358.629 \\
\hline Total compensation of employees & 4216575.358 \\
\hline Salaries & 782354.771 \\
\hline Wages & 3010643.774 \\
\hline Actual social security contributions & 317929.494 \\
\hline Other social benefits & 105647.319 \\
\hline Net taxes on production & 84631.434 \\
\hline Gross operating surplus & 10805151.837
\end{tabular}

Source: National Institute of Statistics and Geography (INEGI), "Sistema de cuentas nacionales de México: fuentes y metodología, año base 2013”, 2017 [online] https://www.inegi.org.mx/contenidos/programas/mip/2013/metodologias/SCNM_Metodo_ MIP_B2013.pdf. 


\section{Simulations}

Once the results of the baseline scenario were obtained, the following combined simulation was carried out: an increase from $10 \%$ to $20 \%$ in the marginal propensity of households to save, and a $20 \%$ subsidy for the purchase of domestic inputs for key sectors. ${ }^{12}$

Subsidies are paid for from government revenues. Logically, by having to devote an increasing percentage to this subsidy (given that $20 \%$ is specified for a growing economy), government revenues and, therefore, spending decrease. But this is more than offset by the boost to real household consumption and by the increase in household income, as a result of the growth in capital stocks, because savings are building up.

Figures 1 and 2 contain the results for labour productivity in two groups of sectors. As can be seen in figure 1, the electric power, food and petroleum and coal derivatives sectors barely react to the increase in savings and the price subsidy for domestic inputs; in contrast, the productivity of the paper, chemical and plastics and rubber products manufacturing industries increase by between $84 \%$ and $98 \%$ above what would be achieved in the absence of any policy.

Although the two policies considered here are relatively simple, the parallel and serial effects triggered by their implementation are very complex because of the numerous interrelations that take place among the productive sectors and among these and the other economic agents, as well as all the effects of second and subsequent loops. In general, the development of a particular industry, as well as its productivity, will depend on several factors, mainly the magnitude of the forward linkages (in this case, the subsidy on domestic inputs), its growing importance as an input supplier for other industries and its capital-labour ratio.

Figure 2 shows the second recipient group. In this case, there is a notable increase in the productivity of primary metal manufacturing industries and manufacturers of fabricated metal products, machinery, computer, communication and other equipment, of electrical appliances, and of transport equipment (automotive industry). The sector with the lowest productivity growth is transport equipment, with 52\%, while primary metal manufacturing industries saw the highest increase, tripling their productivity in just 10 years.

There are also positive effects on the economy as a whole. Total labour productivity in the tenth year is $7 \%$ higher than in the baseline scenario. Figure 3 shows the labour productivity growth index (period $0=1$ ), grouping productive activities into six major sectors: (i) agriculture; (ii) oil and mining; (iii) electricity and gas; (iv) construction; (v) manufacturing; and (vi) services (see annex A4).

In the policy scenario, the agricultural sector increases its productivity by $2 \%$ in the tenth year over the baseline scenario, the oil sector does so by $26.56 \%$, electricity and gas by only $3.63 \%$, construction by $39.8 \%$ and manufacturing by $37.14 \%$, while productivity in the services sector in the tenth year is $4.3 \%$ lower than in the baseline scenario.

These changes mean that the manufacturing sector's share of GDP in the tenth year increases from $19.6 \%$ in the baseline scenario to $21.95 \%$ in the policy scenario, an increase of 2.35 percentage points in just 10 years (see figure 4).

\footnotetext{
12 In addition to economies of scale, the Solow residual can also be affected by increases in total factor productivity and by the introduction of technological improvements.
} 
Figure 1

Comparison of labour productivity growth: baseline scenario versus the policy scenario, low-response sectors

(Index, base year $2017=1$ )
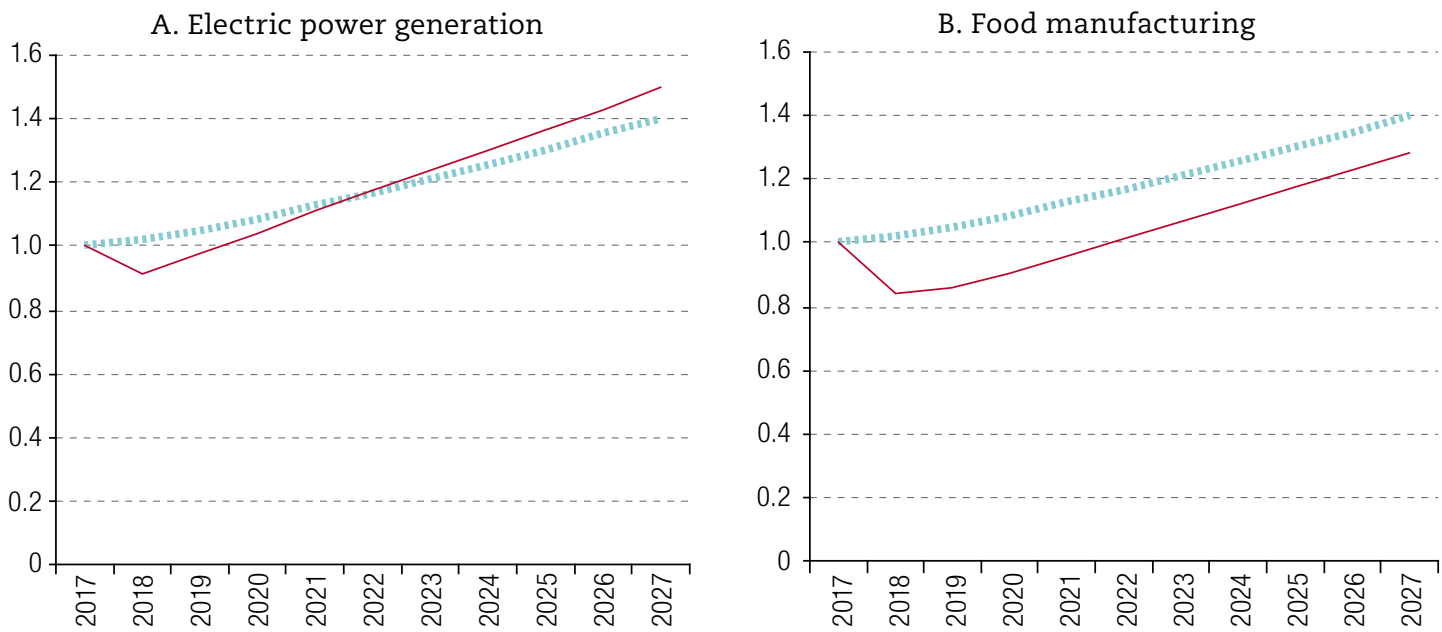

C. Paper manufacturing

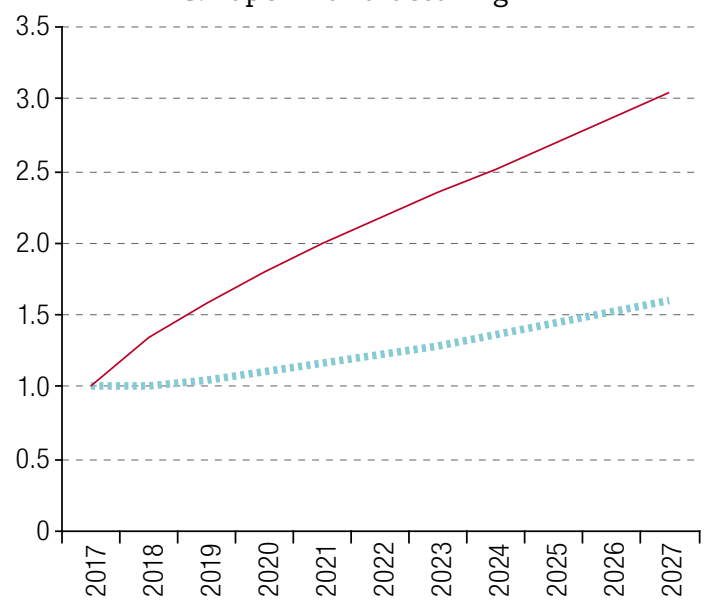

D. Petroleum and coal products manufacturing

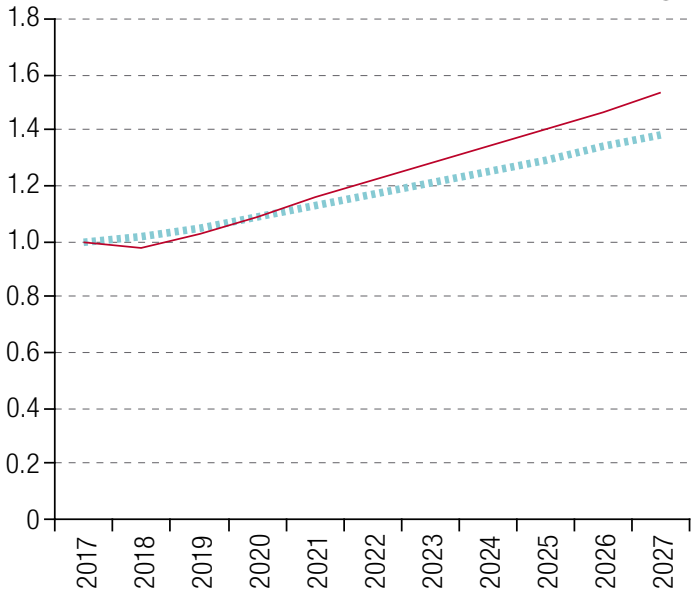

E. Chemical manufacturing

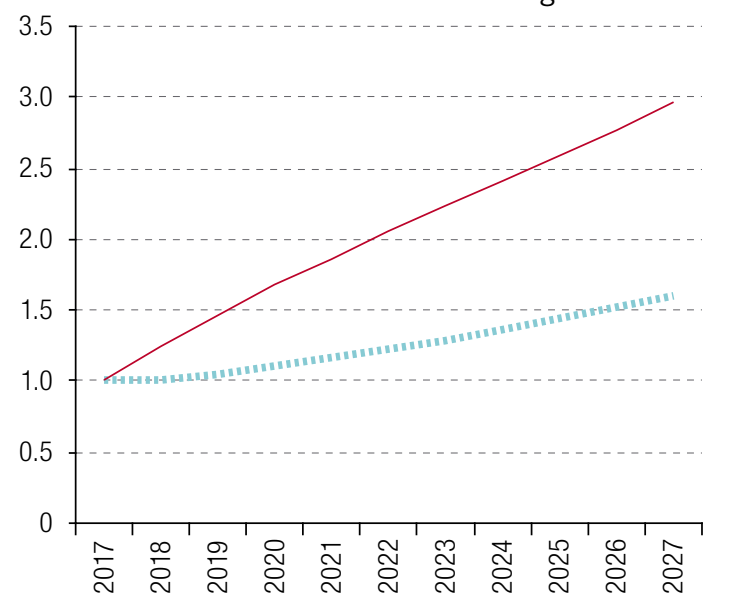

F. Plastics and rubber products manufacturing

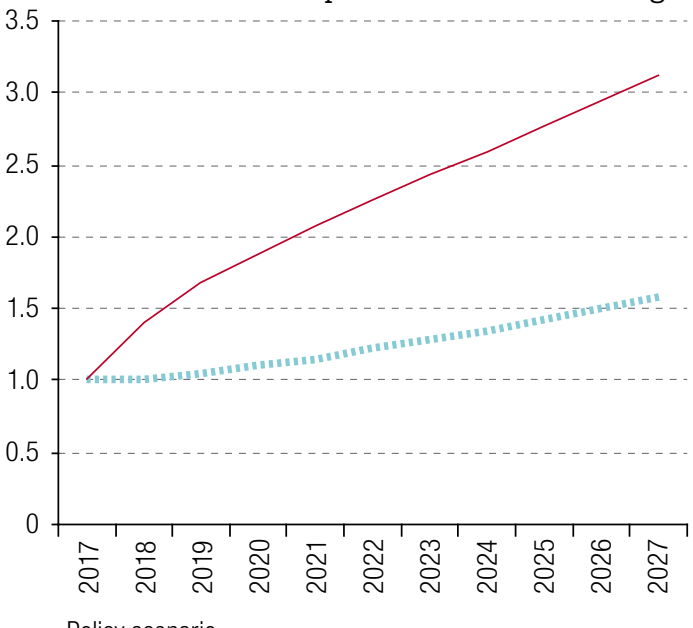

naseline scenario — Policy scenario

Source: Prepared by the authors. 
Figure 2

Comparison of labour productivity growth: baseline scenario versus the policy scenario, high-response sectors

(Index, base year $2017=1$ )

A. Primary metal manufacturing

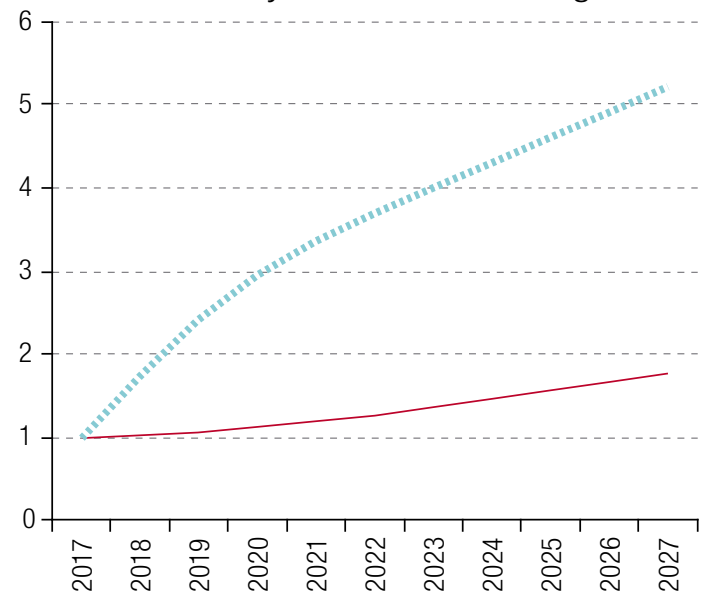

C. Machinery manufacturing

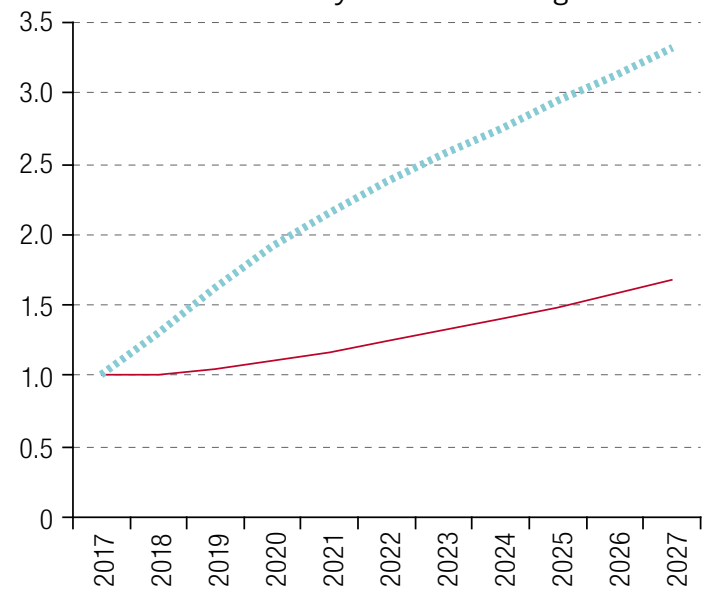

E. Electrical equipment and appliance manufacturing

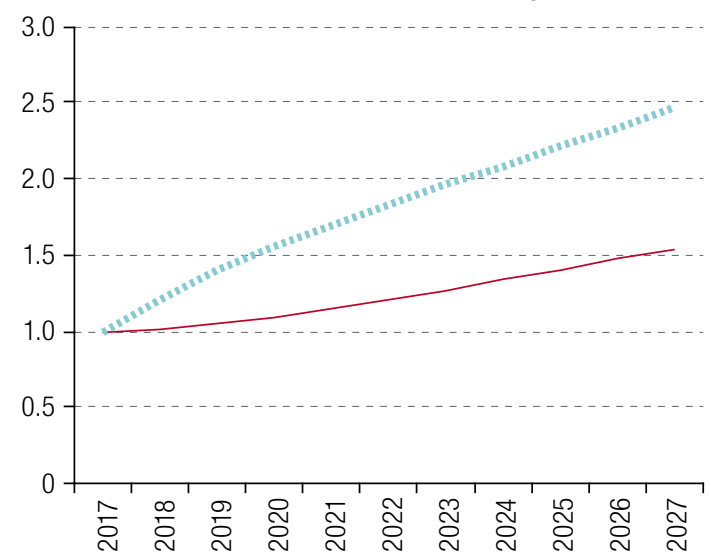

" n . । . Baseline scenario
B. Fabricated metal product manufacturing

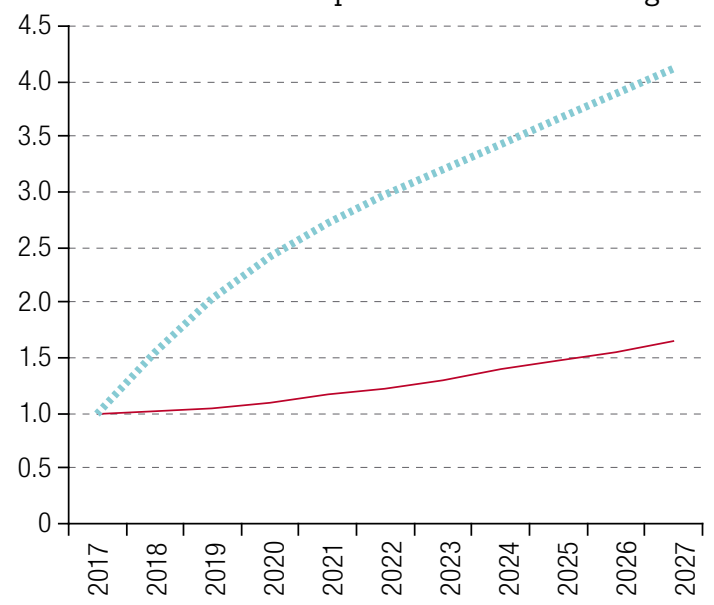

D. Computer, communications, measuring and other equipment manufacturing

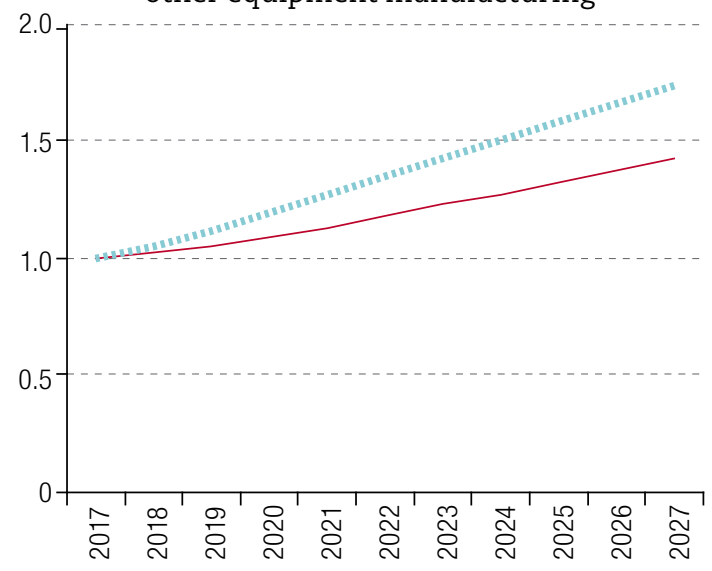

F. Transportation equipment manufacturing

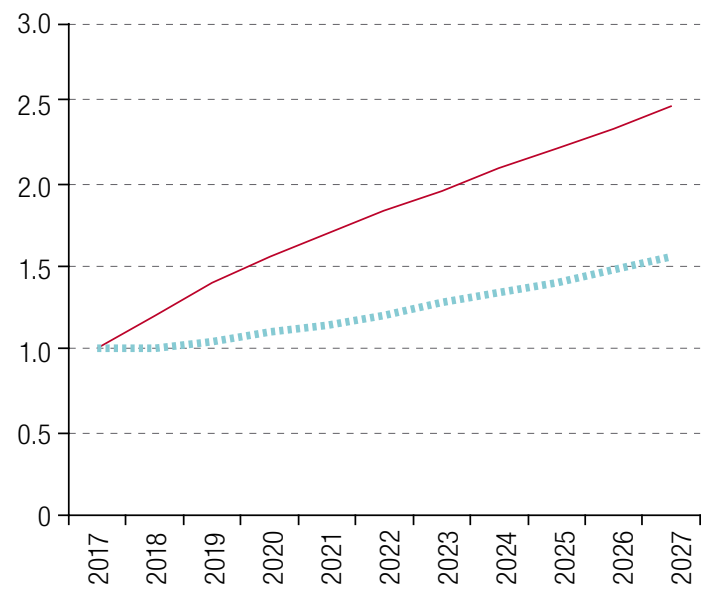

- Policy scenario

Source: Prepared by the authors. 
Figure 3

Productivity index by sector, baseline scenario and policy scenario

(Index, base year $2017=1$ )

A. Agriculture

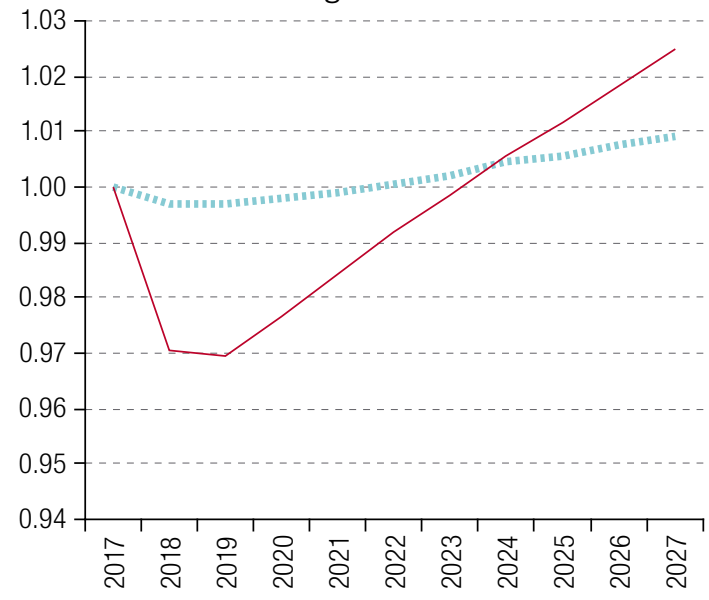

C. Electricity and gas

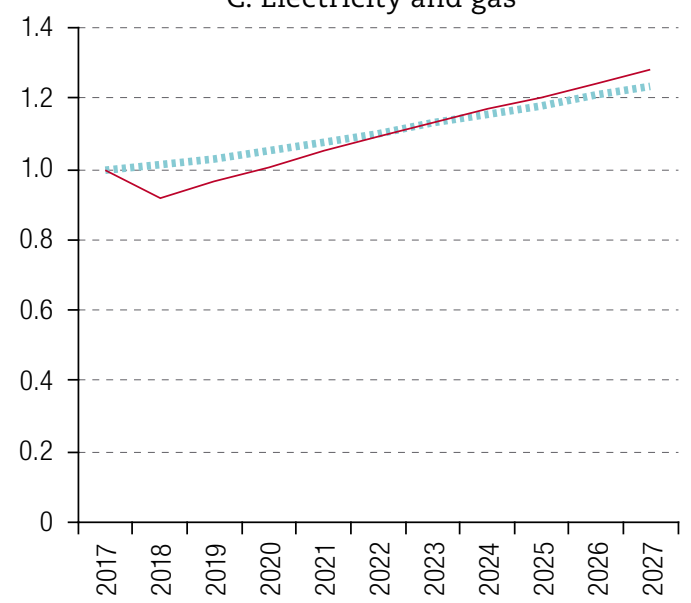

E. Manufacturing

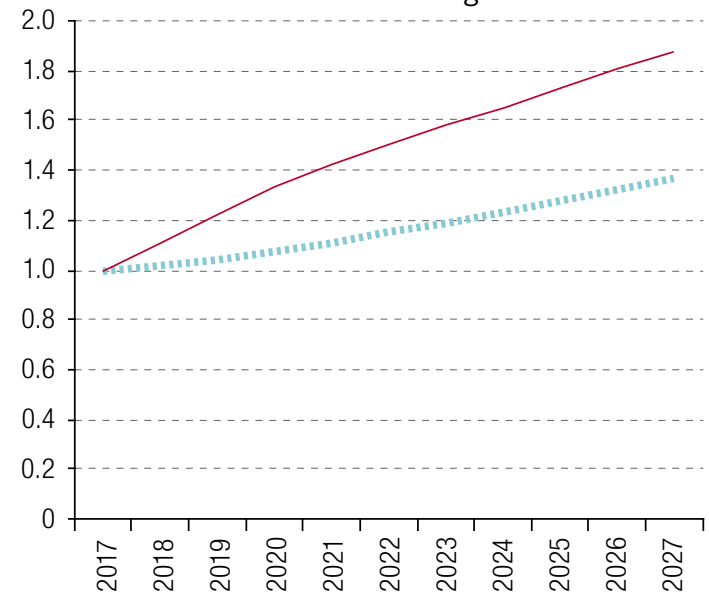

B. Oil and mining

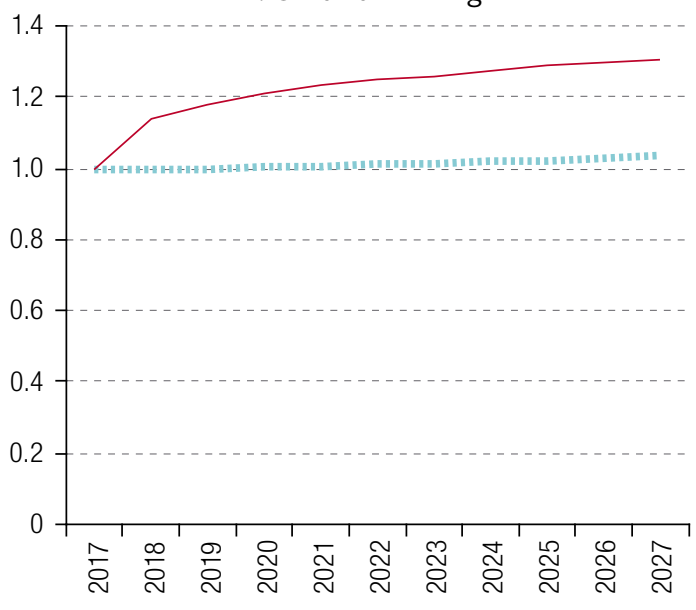

D. Construction

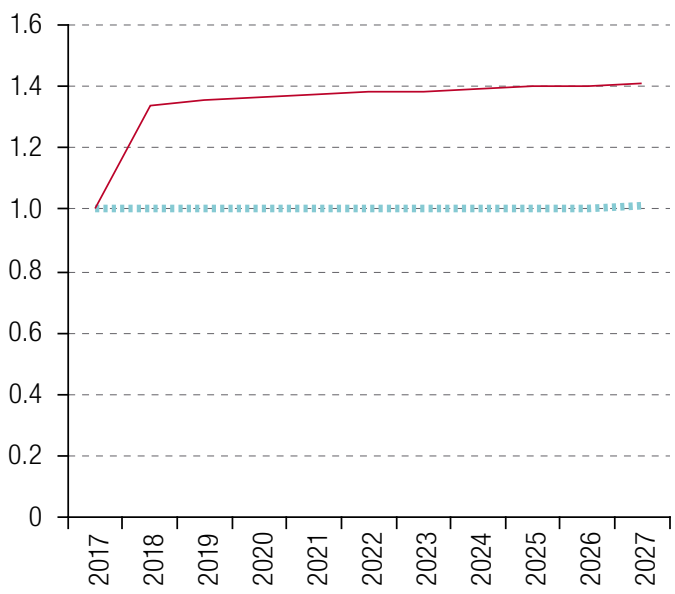

F. Services

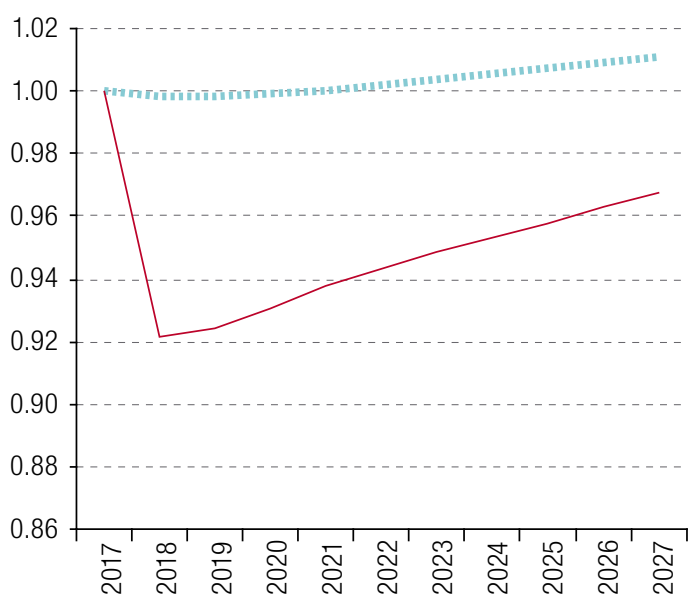

„ n.. Baseline scenario _ _ Policy scenario

Source: Prepared by the authors. 
Figure 4

Manufacturing sector's share of national GDP, baseline scenario and policy scenario (Percentages)

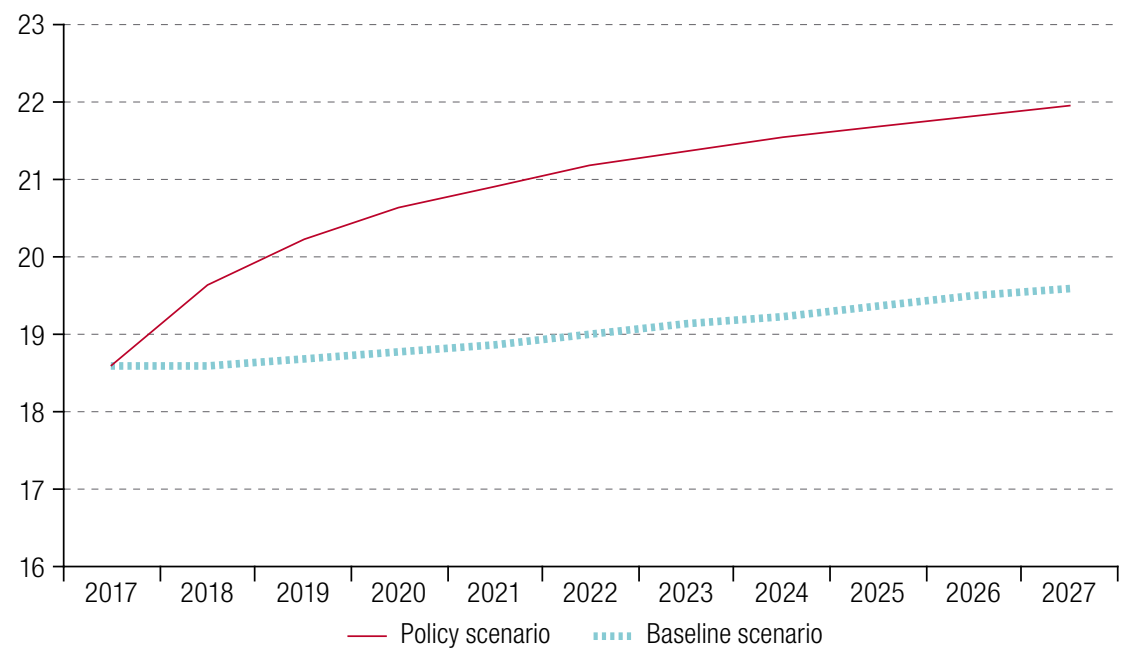

Source: Prepared by the authors.

As Coatsworth (1990) points out, per capita income, despite its limitations, is the best indicator of well-being; if a country's per capita income increases as a result of an economic policy, this indicates that it is potentially better off than before. Under the "compensation test" it can be assumed that, if per capita income increases, the winners could compensate potential losers and keep a remainder. A country's per capita income is closely related to average labour productivity in the economy. ${ }^{13}$

Therefore, in order to know how per capita income will evolve, labour productivity trends must be identified. Figure 5 shows the labour productivity results.

\section{Figure 5}

Labour productivity index

(Base year $2017=1$ )

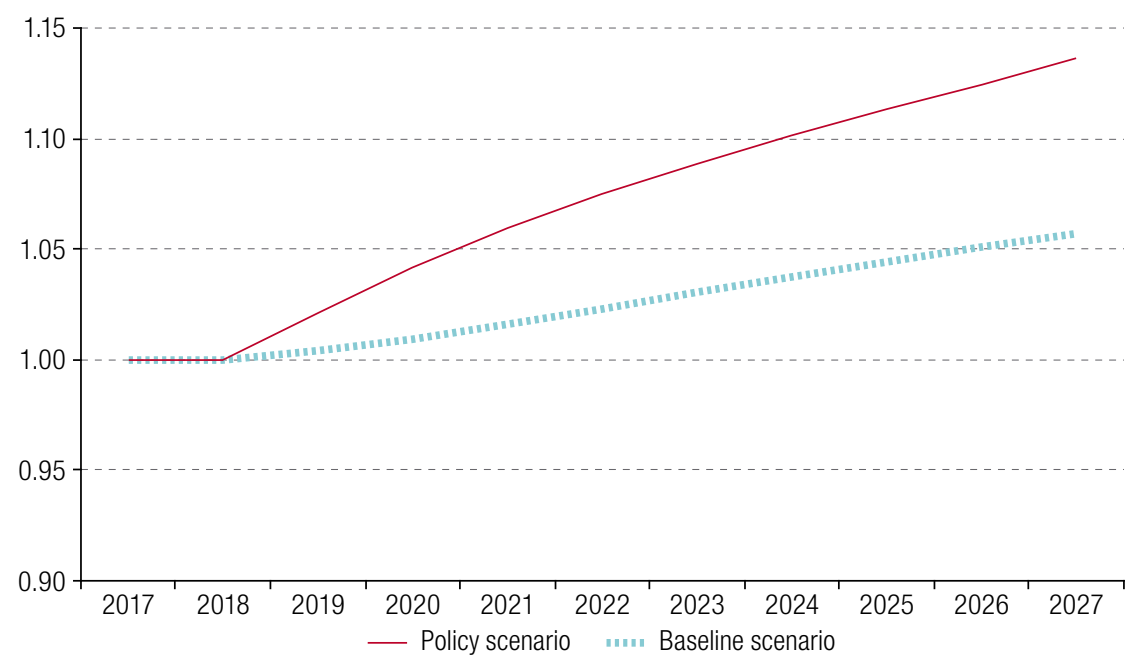

Source: Prepared by the authors.

${ }^{13}$ Per capita GDP $(G D P / P)$ can be disaggregated into average labour productivity $(G D P / E)$, the labour force participation rate $(L / P)$ and the employment rate $(E / L)$, where GDP: gross domestic product; P: population; L: labour force; and E: employment. This is: $\frac{P I B}{P}=\left(\frac{P I B}{E}\right)\left(\frac{L}{P}\right)\left(\frac{E}{L}\right)$. This equation shows that the observed variations in per capita GDP are due to factors related to labour productivity and socioeconomic trends, and the level of economic activity. 
Using data from the statistical annexes of the Informes de Gobierno from several years, on GDP, employment and population, the trajectory of labour productivity and per capita GDP was projected for the period 1988-2027 (see figure 6).

Figure 6

Labour productivity and per capita income, 1988-2027

(Thousands of constant 2008 pesos)

\section{A. Labour productivity}

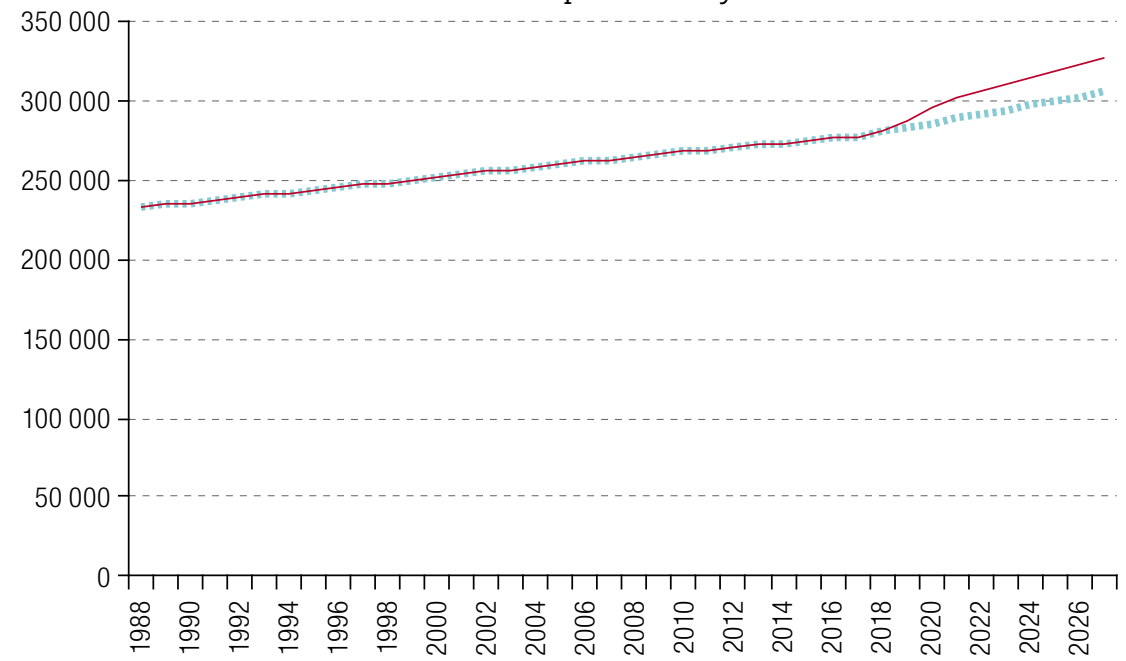

B. Per capita income

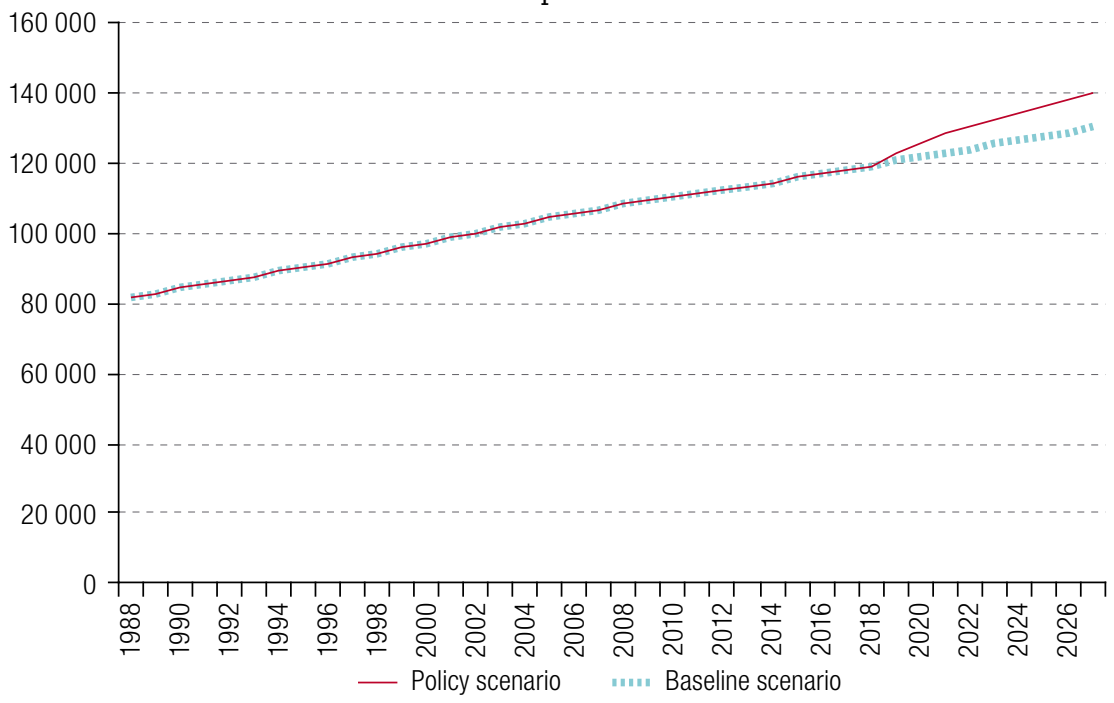

Source: Prepared by the authors, on the basis of Mexico, Informe de Gobierno: anexo estadístico, Mexico City, various years.

To put this in perspective, labour productivity between 1988 and 2017 only increased by 19\%, whereas if the suggested policies are implemented productivity would see growth of $18 \%$ within 10 years. Or put another way, with the suggested reforms, labour productivity in another 10 years would be $18 \%$ higher than it was in 2017, instead of $10 \%$, which is how much it would increase if these reforms are not implemented.

Meanwhile in the baseline scenario, the per capita income growth rate would be $0.95 \%$ over the same period, while it would be $1.67 \%$ under the policy scenario. This result alone would justify adopting a State-led growth strategy, as even between 1988 and 2017, per capita GDP growth was 
less, reaching an average of $1.27 \%$. This was not due to higher productivity (which increased during that period at a rate of just $0.61 \%$ ), but rather to a notable growth in the proportion of the population that joined the labour market, up $0.66 \%$ (that is, the difference between $1.27 \%$ and $0.61 \%)^{14}$ (see figure 7 ).

Figure 7

Employed population as a share of the total population, 1988-2026

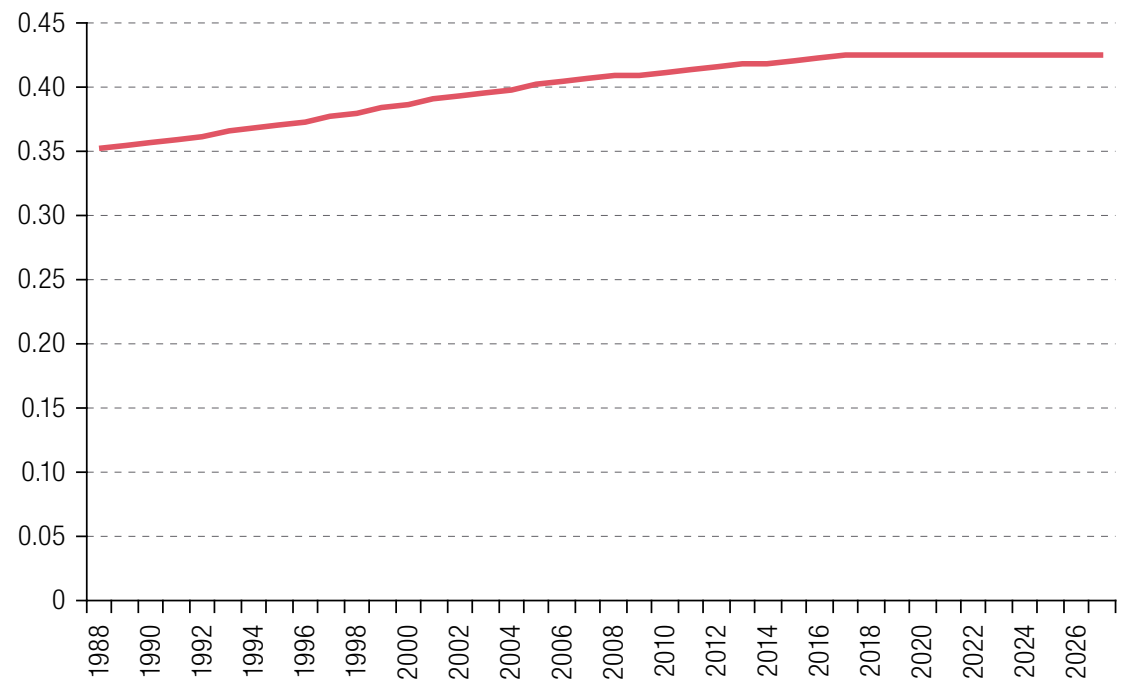

Source: Mexico, 6. Informe de Gobierno: anexo estadístico, Mexico City, 2000; 5. Informe de Gobierno: anexo estadístico, Mexico City, 2000; $4 .^{\circ}$ Informe de Gobierno: anexo estadístico, Mexico City, 2010, and 6. Informe de Gobierno: anexo estadístico, Mexico City, 2018.

This result can be interpreted as follows. If the proportion of the population participating in the labour force remains the same as the trend observed from 1988 to 2017, the average per capita income growth rate for the period 2017-2026 would be $0.62 \%$, compared to $1.67 \%$ if the proposed policies were implemented from 2017 onwards. Looked at another way, if the share of the population in employment continues to trend upwards, the per capita income growth rate would easily exceed $2 \%$ per year in the policy scenario, compared to the $1.27 \%$ rate recorded from 1988 to 2017.

\section{Some conclusions and final comments ${ }^{15}$}

Mexico's economy has been stagnating for more than 30 years, leading us to consider the possibility of breaking a "consensus" that does not even exist in Washington. ${ }^{16}$ This leads us, in turn, to review carefully the economic strategies followed by other countries that have managed to accelerate their economic growth and improve the well-being of their inhabitants in a few decades. These strategies, based on an economy with a strong private sector, but managed by the State, have come to be known as developmental State strategies.

\footnotetext{
${ }^{14}$ Assuming full employment, the per capita GDP growth rate can be expressed as the sum of the growth rate of average labour productivity and the growth rate of the share of the population in employment: $\left(\frac{P I B}{P o b}\right)^{\circ}=\left(\frac{P I B}{E m p}\right)^{0}+\left(\frac{E m p}{P o b}\right)^{0}$ where 0 indicates the growth rates.

15 The objective of this paper has been to analyse the results arising from two policies or two simple changes that the government can introduce. The social accounting matrix we used does not disaggregate all households in the economy, which would allow a differentiated analysis of the various spending (and savings) patterns of these different types of households, according to their consumption patterns. This could be an important future addition for the model, allowing a more complete analysis of the implications for savings and actual consumption.

16 The Washington Consensus refers to a set of 10 economic policy recommendations made in 1989 by John Williamson, for developing countries to help them overcome the debt crisis of the early 1980s. These recommendations include fiscal discipline; capital and foreign exchange market liberalization; international trade liberalization; elimination of barriers to the entry of foreign direct investment; privatization of public enterprises; and protection of property rights, including intellectual property (Williamson, 1990).
} 
As Rodrik (2009) points out, "the Asian experience highlights a deeper point: a sound overall development strategy that produces high economic growth is far more effective in achieving integration with the world economy than a purely integrationist strategy that relies on openness to work its magic".

In order to envisage how a developmental State, as described in the introduction to this article, could be established in Mexico, a CGE model was prepared using just two measures from the strategy's powerful arsenal. We simulated the effects on the Mexican economy of a $20 \%$ subsidy for national inputs granted to 12 of 47 sectors considered key, and an increase in savings from $10 \%$ to $20 \%$. By adopting these two measures alone, it would be possible to almost double the per capita income growth rate and thus prevent, or at least contain, the increasing social disintegration. If other measures were added to the CGE model described in this paper, growth rates would be considerably higher.

The purpose of this exercise is to illustrate what the country could do to shake off economic stagnation by adopting a new strategy. It is obviously not easy to change strategy. There are many internal and external vested interests, which prefer the status quo and are opposed to change and experimentation.

\section{Bibliography}

Alfaro, L. and A. Charlton (2013), "Growth and the quality of foreign direct investment", The Industrial Policy Revolution I: The Role of Government Beyond Ideology, J. Stiglitz and J. Lin (eds.), London, Palgrave MacMillan.

Amsden, A. (1992), "Getting relative prices 'wrong': a summary", Asia's Next Giant: South Korea and Late Industrialization, New York, Oxford University Press.

Antweiler, W. and D. Trefler (2000), "Increasing returns and all that: a view from trade", NBER Working Paper, No. 7941, Cambridge, National Bureau of Economic Research (NBER), October.

Aoki, M., H. Kim and M. Okuno-Fujiwara (eds.) (1998), The Role of Government in East Asian Economic Development: Comparative Institutional Analysis, Clarendon Paperbacks, Oxford, Oxford University Press.

Berasaluce, J. and J. Romero (2018), "La política económica exterior coreana (1948-presente): apertura bajo una estrategia nacional", Cambio de la época de Corea y la revisión de su relación con América Latina, W. Suk-Kyun and J. Ramírez (eds.), Mexico City, El Colegio de México, in press.

Böhm-Bawerk, E. (1891), The Positive Theory of Capital, New York, Pantianos Classics.

Castañeda, A. and G. Garduño (2000), "Rendimientos crecientes a escala en la manufactura mexicana", El Trimestre Económico, vol. 67, No. 266.

CCO Noticias (2015), "Tener un México más moderno, próspero, justo e incluyente es una responsabilidad compartida: EPN (video)", 1 April [online] https://corporacioncomunicativaojeda.wordpress.com/2015/04/01/ tener-un-mexico-mas-moderno-prospero-justo-e-incluyente-es-una-responsabilidad-compartida-epn-video/.

Chandrasekhar, C. (2013), "Financialization as an obstacle to industrialization", The Industrial Policy Revolution II: Africa in the 21st Century, J. Stiglitz, J. Lin and E. Patel (eds.), London, Palgrave MacMillan.

Chang, H. (2003), Globalisation, Economic Development and the Role of the State, London, Third World Network, Zed Books.

Chen, M. (1995), Asian Management Systems: Chinese, Japanese and Korean Styles of Business, London, Routledge.

Chibber, V. (2014), "The developmental State in retrospect and prospect: lessons from India and South Korea", The End of the Developmental State?, M. Williams (ed.), New York, Routledge.

Coatsworth, J. (1990), Los orígenes del atraso: nueve ensayos de historia económica de México en los siglos XVIII y XIX, Mexico City, Alianza Editorial.

Dixon, P. and B. Parmenter (1996), "Computable general equilibrium modelling for policy analysis and forecasting", Handbook of Computational Economics, vol. 1, H. Amman, D. Kendrick and J. Rust (eds.), Amsterdam, North-Holland.

Evans, P. (1995), Embedded Autonomy: States and Industrial Transformation, Princeton, Princeton University Press.

Falck, O., C. Gollier and L. Woessmann (eds.) (2011), Industrial Policy for National Champions, CESifo Seminar Series, Cambridge, MIT Press.

Felipe, J. (ed.) (2015), Development and Modern Industrial Policy in Practice: Issues and Country Experiences, Cheltenham, Asian Development Bank (ADB), Edward Elgar Publishing.

Greenfeld, L. (1993), Nationalism: Five Roads to Modernity, Cambridge, Harvard University Press.

Helpman, E. and P. Krugman (1985), Market Structure and Foreign Trade: Increasing Returns, Imperfect Competition, and the International Economy, Cambridge, MIT Press. 
Hennings, K. (1990), "Roundabout methods of production", Capital Theory, The New Palgrave, J. Eatwell, M. Milgate and P. Newman (eds.), London, Palgrave Macmillan UK.

Hirschman, A. (1968), "The political economy of import-substituting industrialization in Latin America", The Quarterly Journal of Economics, vol. 82, No. 1, February. (1958), The Strategy of Economic Development, New Haven, Yale University Press.

Huff, W. (1995), "The developmental State, government, and Singapore's economic development since 1960", World Development, vol. 23, No. 8, August.

INEGI (National Institute of Statistics and Geography) (2016), "Matriz de Insumo Producto 2012 - actualización. Base 2008" [online] https://www.inegi.org.mx/programas/mip12/2008/default.html\#Documentacion.

Johnson, C. (1987), "Political institutions and economic performance: the government-business relationship in Japan, South Korea, and Taiwan", The Political Economy of the New Asian Industrialism, F. Deyo (ed.), Ithaca, Cornell University Press.

(1982), MITI and the Japanese Miracle: the Growth of Industrial Policy, 1925-1975, Stanford, Stanford University Press.

Kasahara, S. (2013), "The Asian developmental State and the flying geese paradigm", Discussion Papers, No. 213 (UNCTAD/OSG/DP/2013/3), Geneva, United Nations Conference on Trade and Development (UNCTAD), November.

Kim, L. and R. Nelson (eds.) (2000), Technology, Learning, \& Innovation: Experiences of Newly Industrializing Economies, Cambridge, Cambridge University Press.

Kim, Y. (1999), "Neoliberalism and the decline of the developmental State", Journal of Contemporary Asia, vol. 29, No. 4.

Kristof, N. and S. WuDunn (2000), Thunder from the East: Portrait of a Rising Asia, New York, Alfred A. Knopf.

Lee, K. (2013), Schumpeterian Analysis of Economic Catch-up: Knowledge, Path-Creation, and the Middle-Income Trap, Cambridge, Cambridge University Press.

Lee, W. (ed.) (1991), German Industry and German Industrialisation: Essays in German Economic and Business History in the Nineteenth and Twentieth Centuries, New York, Routledge.

Leftwich, A. (1995), "Bringing politics back in: towards a model of the developmental State", The Journal of Development Studies, vol. 31, No. 3, February.

(1994), "The developmental State", Working Paper, No. 6, York, University of York.

Liang, M. (2010), "Confucianism and the East Asian Miracle", American Economic Journal: Macroeconomics, vol. 2, No. 3, July.

Lofgren, H., R. Harris and S. Robinson (2002), A standard computable general equilibrium (CGE) model in Gams, Microcomputers in Policy Research, Washington, D.C., International Food Policy Research Institute (IFPRI).

López-de-Silanes, F., J. Markusen and T. Rutherford (1992), "Complementarity and increasing returns in intermediate inputs: a theoretical and applied general-equilibrium analysis", NBER Working Paper, No. 4179, Cambridge, National Bureau of Economic Research (NBER).

Malerba, F. and others (2016), Innovation and the Evolution of Industries: History-Friendly Models, Cambridge, Cambridge University Press.

Maman, D. and Z. Rosenhek (2011), "The institutional dynamics of a developmental State: change and continuity in State-economy relations in Israel", Working Paper Series, No. 5, Raanana, Open University of Israel.

Mexico (2017), 5. Informe de Gobierno 2016-2017: anexo estadístico, Mexico City.

Minns, J. (2001), "Of miracles and models: the rise and decline of the developmental State in South Korea", Third World Quarterly, vol. 22, No. 6, December.

Monetary Authority of Singapore (1991), Savings-Investment Balances in Singapore: Determinants and Medium-Term Outlook, Singapore.

Myrdal, G. (1971), Economic Theory and Underdeveloped Regions, New York, Harper \& Row.

Nabi, I. and J. Shivakumar (2001), Back from the Brink: Thailand's Response to the 1997 Economic Crisis, Washington, D.C., World Bank.

Nelson, R. (2005), Technology, Institutions and Economic Growth, Cambridge, Harvard University Press. (1996), The Sources of Economic Growth, Cambridge, Harvard University Press.

Nurkse, R. (1952), "Some international aspects of the problem of economic development", The American Economic Review, vol. 42, No. 2, May.

Öniş, Z. (1991), "The logic of the developmental State", Comparative Politics, vol. 24, No. 1, October.

Partida, V. (2008), Proyecciones de la población económicamente activa de México y de las entidades federativas, 2005-2050, Mexico City, National Population Council (CONAPO). 
Park, C. (1979), Korea Reborn: A Model for Development, Englewood Cliffs, Prentice-Hall.

Paul, S. (1979), "Transnational corporations and developing countries: some issues in industrial policy", Economic and Political Weekly, vol. 14, No. 30/32, August.

Permani, R. (2009), "The role of education in economic growth in East Asia: a survey", Asian-Pacific Economic Literature, vol. 23, No. 1, May.

Pierenkemper, T. and R. Tilly (2004), The German Economy during the Nineteenth Century, New York, Berghahn Books.

Polidano, C. (2001), "Don't discard State autonomy: revisiting the East Asian experience of development", Political Studies, vol. 49, No. 3, August.

Prebisch, R. (1959), "Commercial policy in the underdeveloped countries", The American Economic Review, vol. 49, No. 2, May.

Rasgotra, M. (ed.) (2013), Science and Technology in China: Implications and Lessons for India, New Delhi, SAGE Publications India.

Rashid, H. (2013), "Does financial market liberalization promote financial development?: evidence from Sub-Saharan Africa", The Industrial Policy Revolution II: Africa in the 21st Century, J. Stiglitz, J. Lin and E. Patel (eds.), London, Palgrave Macmillan.

Rasmussen, P. (1956), Studies in Inter-Sectoral Relations, Copenhagen, Einar Harcks.

Rodríguez, F. and D. Rodrik (1999), "Trade policy and economic growth: a skeptic's guide to the cross-national evidence", NBER Working Paper, No. 7081, Cambridge, National Bureau of Economic Research (NBER), April.

Rodrik, D. (2009), "Trading in illusions", Foreign Policy, November 18 [online] https://foreignpolicy.com/2009/11/18/ trading-in-illusions/.

(2007), "The real exchange rate and economic growth: theory and evidence", Working Paper, Boston, Weatherhead Center for International Affairs.

Rosenstein-Rodan, P. (1943), "Problems of industrialisation of Eastern and South-Eastern Europe", The Economic Journal, vol. 53, No. 210/211.

Sánchez, I. (2011), "Estancamiento económico en México, manufacturas y rendimientos crecientes: un enfoque kaldoriano", Investigación Económica, vol. 70, №. 277.

Shin, J. and H. Chang (2003), Restructuring Korea Inc., London, RoutledgeCurzon.

Skocpol, T. (1985), "Bringing the State back in: strategies of analysis in current research", Bringing the State Back In, P. Evans, D. Rueschemeyer and T. Skocpol (eds.), Cambridge, Cambridge University Press.

Taylor, M. (2016), The Politics of Innovation: Why some Countries are Better than Others at Science and Technology, New York, Oxford University Press.

The Conference Board (2019), "Total Economy Database ${ }^{\mathrm{TM}}$ - Key Findings" [online database] http://www. conference-board.org/data/economydatabase/.

The Nobel Prize (2020), "The increasing returns revolution in trade and geography" [online] https://www. nobelprize.org/prizes/economic-sciences/2008/krugman/lecture/.

Thompson, M. (1996), "Late industrialisers, late democratisers: developmental States in the Asia-Pacific", Third World Quarterly, vol. 17, No. 4.

Vogel, E. (1991), The Four Little Dragons: The Spread of Industrialization in East Asia, Cambridge, Harvard University Press.

Wade, R. (2003), "What strategies are viable for developing countries today? The World Trade Organization and the shrinking of 'development space'”, Review of International Political Economy, vol. 10, No. 4.

Wan, M. (2008), The Political Economy of East Asia: Striving for Wealth and Power, Washington, D.C., CQ Press.

Weiss, L. (2000), "Developmental States in transition: adapting, dismantling, innovating, not 'normalising'”, The Pacific Review, vol. 13, No. 1.

Williamson, J. (ed.) (1990), "What Washington means by policy reform", Latin American Adjustment: How Much Has Happened?, Washington, D.C., Peterson Institute for International Economics.

Wong, J. (2004), "The adaptive developmental State in East Asia", Journal of East Asian Studies, vol. 4, No. 3, December.

Woo-Cumings, M. (1999), "Introduction: Chalmers Johnson and the politics of nationalism and development", The Developmental State, M. Woo-Cumings (ed.), Ithaca, Cornell University Press.

W Radio (2017), "Quinto Informe de Gobierno de EPN", 2 September [online] http://wradio.com.mx/ radio/2017/09/01/nacional/1504292661_444049.html.

Young, A. (1928), "Increasing returns and economic progress", The Economic Journal, vol. 38, No. 152, December.

Zysman, J. (1983), Governments, Markets, and Growth: Financial Systems and the Politics of Industrial Change, Ithaca, Cornell University Press. 


\section{Annex A1}

\section{Key activities of the Mexican economy}

In accordance with Rasmussen's indices, the key activities of the Mexican economy, for the 2012 social accounting matrix with 47 sectors, developed as part of this research, are those presented in table A1.1.

Table A1.1

Key sectors according to backward and forward linkages

\begin{tabular}{|c|c|c|c|}
\hline & Description & Backward linkages & Forward linkages \\
\hline A6 & Electric power generation, transmission and distribution & 1.155 & 1.422 \\
\hline A10 & Food manufacturing & 1.124 & 1.174 \\
\hline A16 & Paper manufacturing & 1.317 & 1.573 \\
\hline A18 & Petroleum and coal products manufacturing & 1.316 & 4.196 \\
\hline A19 & Chemical manufacturing & 1.125 & 4.349 \\
\hline A20 & Plastics and rubber products manufacturing & 1.310 & 1.389 \\
\hline A22 & Primary metal manufacturing & 1.210 & 2.349 \\
\hline A23 & Fabricated metal product manufacturing & 1.360 & 1.448 \\
\hline A24 & Machinery manufacturing & 1.387 & 1.636 \\
\hline A25 & $\begin{array}{l}\text { Computer, communications, measuring and other electronic equipment, components and } \\
\text { products }\end{array}$ & 2.032 & 2.892 \\
\hline A26 & Electrical equipment, appliance and component manufacturing & 1.576 & 1.324 \\
\hline A27 & Transportation equipment manufacturing & 1.481 & 1.473 \\
\hline
\end{tabular}

Source: Prepared by the authors. 


\section{Annex A2}

\section{Parameters and variables of the recursive dynamic computable general equilibrium (CGE) model}

Table A2.1

CGE-Mx12 parameters

\begin{tabular}{|c|c|c|c|}
\hline Parameter & Description & Parameter & Description \\
\hline \multicolumn{4}{|l|}{ Factors } \\
\hline Captotecon & Total capital in the economy & & \\
\hline Labtotoecon & Total labour in the economy & & \\
\hline \multicolumn{4}{|l|}{ Households } \\
\hline$\tau^{\text {caphous }}$ & Share of households in captotecon & & \\
\hline MPSHOUS & Marginal propensity to save & & \\
\hline$\sigma c p$ & Constant elasticity of substitution & Production & Cobb-Douglas value added \\
\hline$\delta c p$ & Consumer preference parameter & $\alpha c a p_{j}$ & Share of capital \\
\hline Government & & $\alpha l a b_{j}$ & Share of labour \\
\hline$\tau^{\text {ithous }}$ & Household income tax rate & aescva $_{j}$ & Scale parameter \\
\hline$\tau^{\text {itcap }}$ & Company income tax rate & & CES combined input \\
\hline$\tau^{\text {IThousNAT }}$ & Domestic consumption tax & $\sigma i c_{i, j}$ & Elasticity of substitution \\
\hline$\tau^{\text {IThousRoW }}$ & Tax on imported consumer goods & $\delta i c_{i, j}$ & Share of factors \\
\hline$\tau_{j}^{I P}$ & Production tax by activity & $\Phi i c_{i, j}$ & Scale parameter \\
\hline tinvrow & Capital import tax & & Leontief total supply \\
\hline $\mathrm{a}_{\text {trgovhous }}$ & Share of transfers in public expenditure & uirc $_{i, j}$ & Unitary input requirement \\
\hline$a_{\text {savgov }}$ & Share of savings in public expenditure & $u_{\text {urva }}$ & Unitary requirement of value added \\
\hline$a_{\text {conspubrow }}$ & Share of imports in public expenditure & & Aggregate goods for private final consumption \\
\hline $\mathrm{a}_{\text {conspubnat }}$ & Share of consumption in public expenditure & $\operatorname{urcp}_{i}$ & Unitary requirements for the final good \\
\hline$\beta_{\text {CONSPUBi }}$ & Share of each good in public expenditure & RoW & \\
\hline Investment & & $\tau^{\text {caprow }}$ & Share of RoW in captotecon \\
\hline tdeprec & Depreciation rate & $\alpha_{\text {LABROW }}$ & Share of labour in RoW expenditure \\
\hline treinv & Reinvestment rate & $\alpha_{\text {TRROW }}$ & Share of remittances in RoW expenditure \\
\hline$\alpha_{\text {INVRoW }}$ & Share of capital imports in total investment & $\alpha_{\text {SAVROW }}$ & Share of savings in expenditure \\
\hline$\alpha_{I N V N A T}$ & Share of domestic investment in total investment & $\alpha_{\text {EXPORT }}$ & Share of exports in RoW expenditure \\
\hline$\beta_{I N V i}$ & Share of each good in domestic investment & $\beta_{\text {EXPORTi }}$ & Share of each good in exports \\
\hline
\end{tabular}

Source: Prepared by the authors.

Note: IT: income tax; CES: constant elasticity of substitution; RoW: rest of the world. 
Table A2.2

CGE-Mx12 endogenous variables

\begin{tabular}{|c|c|c|c|}
\hline Variable & Description & Variable & Description \\
\hline & HOUSEHOLDS & & GOVERNMENT \\
\hline DISPINC & Household disposable income & ITREV & Income tax revenue \\
\hline HOUSSAV & Household savings & PRODTAXREV & Product and production tax revenue \\
\hline MPSHOUS & Marginal propensity to save & IMPINVREV & Capital import tax revenue \\
\hline PRIVCONSNAT & Private consumption of national goods & GOVREV & Government revenue \\
\hline PRIVCONSROW & Private consumption of imported goods & ITRATEHOUS & Household income tax rate \\
\hline \multirow[t]{2}{*}{ IPCES } & CES index & TRGOVHOUS & Social transfers \\
\hline & SAVINGS-INVESTMENT & SAVGOV & Public savings \\
\hline INVRoW & Investment in imported capital & CONSPUBi & Government consumption \\
\hline INVNATi & Investment in domestic capital & CONSPUBROW & Government imports \\
\hline \multirow[t]{2}{*}{ SAVTOT } & Total savings in the economy & GOVSURP & Public surplus \\
\hline & PRODUCTION & & \\
\hline DEMCAP & Demand for capital & & PRICES \\
\hline$D E M L A B_{j}$ & Demand for labour & Pcap & Price of capital \\
\hline$V A_{j}$ & Value added & Plab & Price of labour \\
\hline DEMINPNAT & Demand for domestic inputs & $P v a_{j}$ & Price of value added \\
\hline DEMINPEXT & Demand for imported inputs & Pinpcombi $_{i}$ & Price of combined inputs \\
\hline DEMINPCOMBI $\left.\right|_{i, j}$ & Demand for combined inputs & Pts $_{i}$ & Price of total supply \\
\hline TOTSUP $_{i}$ & Total supply by activity & $P c p$ & $\begin{array}{l}\text { Price of aggregate private } \\
\text { consumption goods }\end{array}$ \\
\hline \multirow[t]{2}{*}{ DEMCPGDS } & Goods for private consumption & $E R$ & Exchange rate \\
\hline & REST OF WORLD & Prow $_{i}$ & Price of imported inputs \\
\hline REVROW & RoW revenue & ProwCF & Import price for final consumption \\
\hline TRROWHOUS & Transfers from RoW & & \\
\hline SAVRoW & RoW savings & & \\
\hline LABROW & Labour hired by the RoW & & \\
\hline EXPORTi & Exports by activity & & \\
\hline
\end{tabular}

Source: Prepared by the authors.

Note: IT: income tax; CES: constant elasticity of substitution; RoW: rest of the world. 


\section{Annex A3}

\section{Mathematical model}

\section{A. Households}

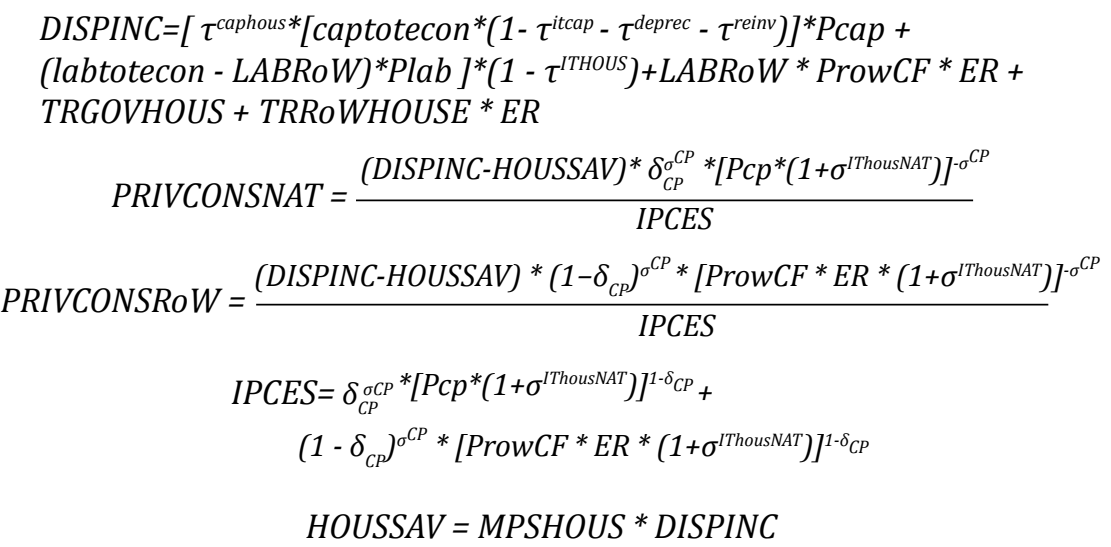

\section{B. Government}

$$
\begin{aligned}
& \text { ITREV }=\left[\tau^{\text {caphous }} * \text { captotecon } *\left(1-\tau^{\text {itcap }}-\tau^{\text {deprec }}-\tau^{\text {reinv }}\right) * \text { Pcap }+\right. \\
& \text { (labtotecon }- \text { LABRoW) } * \text { Plab] }{ }^{*} \tau^{\text {ITHOUS }}+\tau^{\text {itcap } *} \text { captotecon * Pcap } \\
& \text { PRODTAXREV }=\sigma^{\text {IDhousNAT }} * \text { PRIVCONSNAT * Pcp + } \\
& \sigma^{\text {IThogRoW } *} \text { PRIVCONSRoW } * \text { ProwCF } * E R+ \\
& \sum_{j}\left[\operatorname{VA}_{j} * \mathrm{Pva}_{j}+\sum_{i} \text { DEMINSCOMBI }_{i, j}^{*} \text { Pinpcombi }_{i, j}\right] * \tau_{j}^{I P} \\
& I M P I N V R E V=\tau^{\text {invrow } *}\left(I N V R o W^{*} \operatorname{Prow} C F * E R\right) \\
& \text { GOBREV }=I T R E V+P R O D T A X R E V+I M P I N V R E V
\end{aligned}
$$

TRGOVHOUS $=\alpha^{\text {trgovhous } *}$ GOVREV

$$
S A V G O B=\alpha^{\text {savgov * }} \text { GOVREV }
$$

$$
\operatorname{CONSPUB}_{i}=\frac{\beta_{i}^{\text {conspub } *} \alpha^{\text {conspubnat } *} G O B R E V}{P t s_{i}}
$$

$$
\text { CONSPUBRoW }=\frac{\alpha^{\text {conspubrow * }} G O B R E V}{\text { ProwCF }{ }^{*} E R}
$$

GOVSURP = GOVREV - TRGOVHOUS - GOVSAV -

$$
\text { CONSPUBRoW }{ }^{*} P_{\text {RoW }} C F^{*} E R-\sum_{i} \text { CONSPUB }_{i}^{*} \text { Pts }_{i}
$$




\section{Savings-investment}

$$
\begin{gathered}
\text { TOTSAV }=\text { HOUSSAV }+ \text { GOVSAV }+ \text { SAVRoW } W^{*} E R+ \\
\left(\tau^{\text {deprec }}+\tau^{\text {reinv }}\right) * \text { captotecon * Pcap } \\
I N V R o W=\frac{\alpha^{\text {invrow * }} \text { SAVTOT }}{\text { ProwCF }^{*} E R^{*}\left(1+\tau^{\text {invrow }}\right)}
\end{gathered}
$$

Two proposals for savings-investment closures are included in the section on macroeconomic closures.

\section{Production factors}

See the section on macroeconomic closures.

\section{E. Production}

Cobb-Douglas production function applied to value added. To produce the value added (compound factor), we used a Cobb-Douglas aggregation of constant returns to scale, where minimizing total cost generates optimal demands:

$$
\begin{aligned}
\operatorname{DEMCAP}_{J} & =\frac{\alpha c a p_{j}{ }^{*} V A_{j}{ }^{*} P v a_{j}}{P c a p} \\
D E M L A B_{J} & =\frac{\alpha l a b_{j}{ }^{*} V A_{j}{ }^{*} P v a_{j}}{P l a b}
\end{aligned}
$$

With $\alpha c a p_{j}+\alpha l a b_{j}=1$. And the assumption of perfect competition:

$$
V A_{j}=\operatorname{aescva}_{j}^{*} D E M C A P_{j}^{\alpha c a p_{j} *} D E M L A B_{j}^{\alpha l a b_{j}}
$$

In accordance with section II, for each productive sector $j$, we use the functional form:

$$
Y_{t}=\left(\frac{V A_{t}}{V A_{t-1}}\right)^{\mu} \operatorname{aescva}_{t}^{*} \operatorname{DEMCAP}_{t}^{\alpha c a p_{j} * D E M L A B_{t}^{\alpha l a b_{j}}}
$$

where $\mu=1.5$ for the key activities and $\mu=0$ for all other activities.

CES production of combined inputs. By minimizing the cost, the optimal demands are:

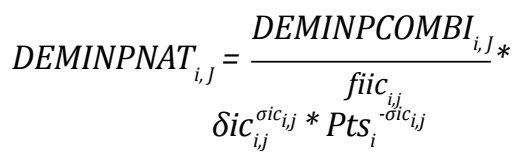

$$
\begin{aligned}
& \overline{\left[\delta i c_{i, j}^{\sigma i c_{i, j}} * P t s_{i}^{-\sigma i c_{i, j}}+\left(1-\delta i c_{i, j}\right)^{\sigma i c_{i, j} *}\left(\operatorname{Prow}_{i} * E R\right)^{\left.1-\sigma i c_{i, j}\right]^{\sigma i c_{i, j} /\left(\sigma i c_{i, j}-1\right)}}\right.} \\
& \text { DEMINPEXT }_{i, J}=\frac{\text { DEMINPCOMBI }_{i, J}}{\text { fiic }_{i, j}} * \\
& \left(1-\delta i c_{i, j}\right)^{\sigma i c_{i, j} *}\left(\operatorname{Prow}_{i}^{*} E R\right)-\sigma i c_{i, j} \\
& \overline{\left[\delta i c_{i, j}^{\sigma i c_{i, j}} * P t s_{i}^{-\sigma i c_{i, j}}+\left(1-\delta i c_{i, j}\right)^{\sigma i c_{i, j} *}\left(\operatorname{Prow}_{i} * E R\right)^{1-\sigma i c_{i, j}}\right]^{\sigma i i_{i, j} /\left(\sigma i i_{i, j}-1\right)}}
\end{aligned}
$$


And the assumption of perfect competition:

$$
\begin{aligned}
& \text { Pinscombi }_{i, j}=\frac{1}{\text { fiic }_{i, j}} * \\
& {\left[\delta i c_{i, j}^{\sigma i c_{i, j} *} \operatorname{Pts}_{i}^{1-\sigma i c_{i, j}}+\left(1-\delta i c_{i, j}\right)^{\sigma i c_{i, j} *}\left(\operatorname{Prow}_{i} * E R\right)^{1-\sigma v a_{i, j}}\right]^{1 /\left(1-\sigma i c_{i, j}\right)}}
\end{aligned}
$$

Leontief production function of total supply (total gross production). By minimizing the cost, the optimal demands are:

$$
\begin{gathered}
\operatorname{VA}_{j}=\operatorname{ruva}_{j}{ }^{*} \operatorname{TOTSUP}_{j} \\
\operatorname{DEMINPCOMBI}_{i, j}=\operatorname{uirc}_{i, j}{ }^{*} \text { TOTSUP }_{j}
\end{gathered}
$$

And the assumption of perfect competition:

$$
\text { Pts }_{j}=\left[\operatorname{urva}_{j}{ }^{*} P v a_{j}+\sum_{i} \operatorname{uirc}_{i, j} * \operatorname{Pinpcombi}_{i, j}\right] *\left(1+\tau_{j}^{I P}\right)
$$

Leontief production function of national aggregate goods for private final consumption:

$$
\begin{aligned}
\text { DEMCPGDS }_{i} & ={\text { PRIVCONSNAT * } \text { urcp }_{i}} \\
\text { Pcp } & =\sum_{i} \text { Pts }_{i}{ }^{*} \text { urcp }_{i}
\end{aligned}
$$

\section{F. Rest of the world (RoW)}

At RoW prices.

$$
\begin{aligned}
& \text { REVROW }=[\text { PRIVCONSRoW }+ \text { CONSPUBRoW }+ \text { INVRoW }] * \text { ProwCF } \\
& +\sum_{i} \sum_{j} \text { DEMINSEXT }_{i, j} * \text { Prow }_{i} \\
& +\tau^{\text {caprow } *} \text { captotecon }\left(1-\tau^{\text {itcap }}-\tau^{\text {deprec }}-\tau^{\text {reinv }}\right) \frac{P_{C A P}}{E R} \\
& \text { TRROWHOUS }=\alpha_{\text {trow }} * \text { REVROW } \\
& S A V R O W=\alpha_{\text {SAVrow }} * \text { REVROW } \\
& L A B R O W=\alpha_{\text {labrow }} \frac{R E V R O W}{P_{\text {RoW }} C F} \\
& \text { EXPORT }_{i}=\text { Bexport }_{i}^{*} \alpha_{\text {export }} \frac{\text { REVROW }_{\text {Pts }_{i} / E R}}{\text { ex }}
\end{aligned}
$$

Small country scenario:

$$
\begin{gathered}
\text { ProwCF }^{=} 1 \\
\text { Prow }_{i}=1
\end{gathered}
$$

\section{G. Macroeconomic closures}

The sum of capital (labour) demands in each activity is equal to the total capital (labour) of the economy (full employment).

$$
\begin{gathered}
\sum_{j} D_{E M C A P_{j}}=\text { captotecon } \\
\sum_{j} D E M L A B_{j}=\text { labtotecon }- \text { LABRoW }
\end{gathered}
$$

Assuming that households' propensity to save does not vary significantly in the face of relatively small changes:

$$
\left[\text { SAVTOT }-I N V R o W * \operatorname{ProwCF}^{*} E R\left(1+\tau^{\text {invrow }}\right)\right] \beta_{\text {inv }}=\operatorname{INVNAL}_{i}{ }^{*} \operatorname{Pts}_{i}
$$


By fixing investment, the marginal propensity to save remains variable:

$$
\begin{array}{r}
\text { HOUSSAV }=\sum_{i} \operatorname{INVNAT}_{i}^{*}{ }^{*} \operatorname{Pts}_{i}+I N V R o W^{*} \operatorname{ProwCF}^{*} E R\left(1+\tau^{\text {invrow }}\right) \\
-S A V G O V-\left(\tau^{\text {deprec }}+\tau^{\text {reinv }}\right) * \text { captotecon }{ }^{*} P_{C A P}-S A V R o W^{*} E R
\end{array}
$$

Lastly, the total demand for goods has to be equal to the total supply:

$$
\text { TOTSUP }_{i}=\sum_{j} \text { DEMINPNAT }_{i, j}+\text { DEMCPGDS }_{i}+\text { CONSPUB }_{i}+I N V_{i}+\text { EXPORT }_{i}
$$

\section{H. Recursive dynamics}

The exercise was carried out across 10 time periods $(t=1,2, \ldots, 10)$. As noted above, labour is updated in each period according to the (constant) growth rate of the economically active population (EAP).

With regard to capital, its real return $\left(k t r_{t}\right)$ is given by the total value of income divided by total savings, multiplied by the growth rate $g_{t}$. Looked at another way: $g_{t}=\left(S_{A V T O T}{ }^{*}{ } t_{t}\right) /\left(\right.$ Pcap $_{t}$ * captotecon $t_{t}$ ), which means that savings multiplied by their return and divided by total income gives the growth rate, as savings are the difference between the income of two periods. Accordingly, capital is updated for each period as follows:

$$
\begin{gathered}
\text { captotecon }_{t+1}=\left(1+g_{t}\right) * \text { captotecon }_{t} \\
g_{t}=\text { SAVTOT }_{t} * \text { ktr }_{t} /\left(\text { Pcap }_{t} * \text { captotecon }_{t}\right)
\end{gathered}
$$




\section{Annex A4}

\section{Activities and their aggregate in large sectors}

\begin{tabular}{|c|c|c|}
\hline Large sector & Number & Activity \\
\hline \multirow[t]{2}{*}{ Agriculture } & 1 & Agriculture \\
\hline & 2 & $\begin{array}{l}\text { Animal breeding and production; forestry; fishing, hunting and trapping; } \\
\text { services related to agricultural and forestry activities }\end{array}$ \\
\hline \multirow[t]{3}{*}{ Oil and mining } & 3 & Oil and gas extraction \\
\hline & 4 & Metallic and non-metallic ore mining, except oil and gas \\
\hline & 5 & Services related to mining \\
\hline \multirow[t]{2}{*}{ Electricity and gas } & 6 & Electric power generation, transmission and distribution \\
\hline & 7 & Water and gas supply through mains to the final consumers \\
\hline \multirow[t]{2}{*}{ Construction } & 8 & Construction \\
\hline & 9 & Civil engineering construction works; specialized construction works \\
\hline \multirow[t]{19}{*}{ Manufacturing } & 10 & Food industry \\
\hline & 11 & Beverage and tobacco industries \\
\hline & 12 & Textile inputs manufacturing and textiles finishing, and textile products manufacturing, except apparel \\
\hline & 13 & Apparel manufacturing \\
\hline & 14 & Leather and hide tanning and finishing, and manufacturing of leather, hide and allied products \\
\hline & 15 & Wood product manufacturing \\
\hline & 16 & Paper manufacturing \\
\hline & 17 & Printing and related support activities \\
\hline & 18 & Petroleum and coal products manufacturing \\
\hline & 19 & Chemical manufacturing \\
\hline & 20 & Plastics and rubber products manufacturing \\
\hline & 21 & Non-metallic mineral product manufacturing \\
\hline & 22 & Primary metal manufacturing \\
\hline & 23 & Fabricated metal product manufacturing \\
\hline & 24 & Machinery manufacturing \\
\hline & 25 & Computer, communications, measuring and other equipment manufacturing \\
\hline & 26 & Electrical equipment, appliance and component manufacturing \\
\hline & 27 & Transportation equipment manufacturing \\
\hline & 28 & Miscellaneous manufacturing \\
\hline \multirow[t]{19}{*}{ Services } & 29 & Retail trade \\
\hline & 30 & Transportation \\
\hline & 31 & Postal, parcel and warehousing services \\
\hline & 32 & Mass media information \\
\hline & 33 & $\begin{array}{l}\text { Central bank, non-stock exchange credit and financial intermediation institutions, } \\
\text { and stock market, currency exchange and financial investment activities }\end{array}$ \\
\hline & 34 & Surety, insurance and pension companies \\
\hline & 35 & Real estate services \\
\hline & 36 & Rental and leasing of tangible goods, and rental services of trademarks, patents and franchises \\
\hline & 37 & Professional, scientific and technical services \\
\hline & 38 & Corporate services \\
\hline & 39 & Business support services, and waste management and remediation services \\
\hline & 40 & Educational services \\
\hline & 41 & Outpatient medical services and related services \\
\hline & 42 & Hospitals; social assistance and health care residential facilities; other social assistance services \\
\hline & 43 & Cultural and sporting recreation services and other recreational services \\
\hline & 44 & Temporary accommodation services \\
\hline & 45 & Food and beverage preparation services \\
\hline & 46 & Other services, except government activities \\
\hline & 47 & $\begin{array}{l}\text { Legislative, governmental and justice administration activities, and activities of international } \\
\text { and extraterritorial organizations }\end{array}$ \\
\hline
\end{tabular}

Source: Prepared by the authors. 